Linha D'Água (Online), São Paulo, v. 30, n. 1, p. 89-114, jun. 2017

\title{
VOZES E PODER NO TELEJORNAL: O \\ FUNCIONAMENTO DO DISCURSO REPORTADO \\ NO JORNAL NACIONAL DA REDE GLOBO
}

\section{VOICES AND POWER IN THE TV NEWS BROADCAST: THE WORKINGS OF THE REPORTED SPEECH IN REDE GLOBO'S NATIONAL NEWS}

\author{
Dóris de Arruda Carneiro da Cunba* \\ Universidade Federal de Pernambuco, Recife, PE, Brasil \\ Universidade Católica de Pernambuco, Recife, PE, Brasil
}

\begin{abstract}
Resumo: Este artigo se propõe a apresentar algumas reflexões sobre vozes e poder no telejornalismo, com base num estudo de caso, uma notícia do Jornal Nacional do Grupo Globo. A questão central é sobre o poder do editor e dos jornalistas na construção da notícia, constituída majoritariamente por meio de discursos reportados. No telejornal analisado, as formas de inserção do heterodiscurso são pouco diversificadas e aparentemente neutras: o discurso citante do editor e apresentador chama a jornalista que introduz outras vozes - fragmentos de entrevista, de declarações oficiais, de testemunhos, na forma de citação direta ou indireta. A estratégia é não usar formas linguísticas que mostrem explicitamente seus pontos de vista. No entanto, as vozes selecionadas servem para ilustrar e acentuar os pontos de vista velados da empresa e dos seus profissionais, funcionando como argumento de autoridade. Dessa forma, a TV Globo exerce seu poder manipulando o grande público, pouco atento a essa estratégia, que faz crer que a notíia do Jornal Nacional é neutra e detentora de verdade.
\end{abstract}

Palavras-chave: Vozes; Poder, Notícia, Jornal Nacional; Rede Globo.

Abstract: This article presents some reflections on the voices and power of journalism on $T V$, based on a study of a news report in Jornal Nacional, via Rede Globo, an evening Brazilian TV news program. The central question is the power of the editor and the journalists in the construction of the news, constituted mostly by the use of reported speech. In the analyzed newscast, the ways the heterodiscourse are inserted are little diversified and apparently neutral: the citing discourse of the editor and the one of the presenter calls the journalist who introduces other voices - fragments of interviews, official statements and testimonies, in the form of direct or indirect citation. The strategy is not to use linguistic forms that explicitly state their points of view. However, the selected voices serve to illustrate and highlight the veiled views of the company and its professionals, acting as an authoritative argument. This way, TV Globo exercises its power by manipulating a large audience, unaware of this strategy, who believes that the news broadcast on Jornal Nacional is neutral and truthful.

Keywords: Voices; Power; News; Jornal Nacional; Rede Globo.

* Professora Doutora da Universidade Federal de Pernambuco - UFPE; e da Universidade Católica de Pernambuco - UNICAP, Recife, PE, Brasil/ CNPq; doris@ufpe.br 
Linha D'Água (Online), São Paulo, v. 30, n. 1, p. 89-114, jun. 2017

\section{Introdução}

Existem numerosos trabalhos sobre linguagem e poder e poder da mídia, o quarto poder, ao lado do Executivo, Legislativo e Judiciário ${ }^{1}$, muitos deles realizados por estudiosos do campo da comunicação, da sociologia, da ciência política, os primeiros a chamar a atenção, de acordo com Toback e Jacobs (2013), para os processos de produção jornalística e a examinar o impacto das relações econômicas e políticas sobre a mídia. Chomsky $(2003 ; 2015)$ denuncia há décadas o poder econômico dos megagrupos midiáticos e a manipulação do público pela mídia.

A noção de quarto poder surgiu, segundo Ramonet (2003), devido ao sentido ético das mídias e à coragem dos jornalistas de serem porta-voz dos sem voz, uma vez que criticavam, se contrapunham democraticamente a decisões injustas contra pessoas inocentes. Mas nos últimos trinta anos, com a chamada globalização e com o crescimento do capitalismo financeiro, a mídia perdeu a função de contrapoder, conforme o autor. Os meios de comunicação de massa, incluindo a internet, unem-se cada vez mais, de modo que a configuração atual do sistema midiático está sob forte concentração monopólica em torno de megagrupos e dinastias familiares. O poder desde então passou a ser detido por empresas globais, inspiradores das políticas do Fundo Monetário Internacional, Banco Mundial e Organização Mundial do Comércio. Essa mudança provocou uma metamorfose nos meios de comunicação de massa. Conforme o autor, as megaempresas que hoje detêm todos os meios de comunicação inclusive a internet não se preocupam mais em ser um quarto poder, em denunciar abusos, em corrigir defeitos da democracia e nem agir como contra poder. Querem sobretudo garantir o seu gigantismo, subordinando informações de interesse coletivo a ambições lucrativas. Para Ramonet (2003), quando podem se constituir em quarto poder, os grupos econômicos midiáticos acrescentam-se aos outros poderes - político e econômico - para esmagar os cidadãos, impor a lógica do mercado e o pensamento neoliberal como únicos.

Buscando analisar o impacto decorrente do desenvolvimento da internet no mundo da cultura, Rieffel (2014) também aponta a questão econômica como

Tomei conhecimento ao final da redação deste artigo de um livro do jornalista Paulo Henrique Amorim intitulado $O$ quarto poder, de modo que não houve tempo hábil para a leitura.

CUNHA, D. A. C. Um olhar sobre vozes e poder no telejornal: o funcionamento do discurso 
Linha D'Água (Online), São Paulo, v. 30, n. 1, p. 89-114, jun. 2017

responsável pelo agrupamento das mídias em empresas nacionais e sobretudo mundiais cujo objetivo principal é conquistar novos mercados. Esse contexto cada vez mais concorrencial favoreceu o desenvolvimento da concentração das mídias, com a compra de grandes grupos de comunicação, a financeirização do setor e a busca de rentabilidade máxima.

Esse ponto de vista do sociólogo francês é partilhado por Souza $(2015 ; 2016)$ que analisa o controle dos conteúdos nas mídias pelas grandes corporações, sob o comando do capital financeiro, nas últimas décadas. Ele postula que a grande imprensa, especialmente a televisão, uma concessão pública no Brasil, distorce sistematicamente a realidade social por dinheiro, que vem da propaganda de empresas com interesse direto no rentismo e da propaganda oficial de todo tipo, em vez de informar. Na realidade, a imprensa, incluindo a televisiva, não distorce a realidade social, mas é responsável pela construção dos acontecimentos (MOIRAND, 2007; 2016), por meio dos processos de seleção de conteúdos, de articulação, de circulação e de repetição de discursos e imagens, em cada momento discursivo ${ }^{2}$.

Outros estudos apontam o caráter denunciativo do jornalismo (DINES; VOGT; MELO, 1997, apud Cordeiro, 2017) bem como o agendamento ${ }^{3}$, como responsáveis também pela criação de eventos. Souza $(2015 ; 2016)$ vai mais além: para ele, as mídias, e outras instituições, "pautaram” os acontecimentos de junho de 2013 que resultaram na mudança do cenário político brasileiro em 2016.

Enquanto analista do discurso e em razão do modesto objetivo desse artigo, as discussões sobre mídia, televisão e poder como um todo serão bastante sucintas. Nos outros campos, há uma tendência para abordagens globais da mídia ou do telejornal, ao passo que no campo da linguística e das análises do discurso os trabalhos se apoiam na materialidade linguística, em indícios, categorias de análise e procedimentos discursivos, para descrever e interpretar o funcionamento dos

2 Utilizamos livremente a noção de momento discursivo proposta por Moirand (2007), para referir-se a um "evento /.../ que dá lugar a uma abundante produção midiática e que deixa igualmente alguns indícios a mais ou menos longo prazo nos discursos produzidos ulteriormente, a propósito de outros eventos".

3 A noção de agendamento da mídia foi usada por McCombs e Shaw (1972 apud Cordeiro, 2017), para se referir ao que é pautado pelos editores, que definem o que será objeto de circulação, retomadas e comentários.

CUNHA, D. A. C. Um ohar sobre vozes e poder no telejornal: o funcionamento do discurso 
Linha D'Água (Online), São Paulo, v. 30, n. 1, p. 89-114, jun. 2017

gêneros da mídia. Essa abordagem explica a dificuldade de se trabalhar com um grande corpus no curto espaço de um artigo e a razão de se apresentar aqui um estudo de caso, uma notícia de seis minutos produzida pelo Jornal Nacional da Rede Globo. Como a notícia é o lugar de articulação ou relação de discursos (Cunha 2002), a proposta é examinar os procedimentos composicionais do telejornal e mais especificamente a seleção e introdução de discursos reportados. $\mathrm{O}$ foco é o discurso emoldurador, ou seja, as falas dos jornalistas e as palavras por eles selecionadas, que revelam as avaliações, orientadas para o ouvinte e para o conteúdo do enunciado. O ato de nomear ${ }^{4}$, como mostram Siblot (1998), Moirand (2004; 2007; 2009; 2014), Veniard (2013), entre outros, já é um ponto de vista. Trata-se, portanto, de refletir sobre o poder do editor e apresentador do telejornal, ao colocar em cena as vozes escolhidas, que servem como argumento de autoridade, ilustram e acentuam o ponto de vista da empresa, além de criar novos eventos nessa orquestração de discursos.

\section{1 "Sobre a televisão"}

Retomo o título do livro de Bourdieu (1996) para fazer algumas considerações sobre a televisão que, segundo o sociólogo, apresenta perigos políticos na medida em que tem o poder de produzir efeito de real, ou seja, de fazer ver e de fazer crer no que ela faz ver. Para Bourdieu (1996), a televisão caminhou de um pretendido instrumento de registro para se tornar um instrumento de criação da realidade, descrevendo e prescrevendo o mundo social, de modo que se tornou árbitro de acesso à existência político-social. ${ }^{5}$

Muitos estudiosos lembram Gramsci (1916) que analisou o funcionamento da "imprensa burguesa", a serviço do que ele chama classe dominante:

4 Título do livro L'acte de nommer (Cislaru et al., 2007), que se situa no campo do dialogismo da nominação, desenvolvido inicialmente pelos pesquisadores do campo da praxemática e depois daqueles que atuam no campo da análise do discurso.

5 É importante salientar que o texto foi escrito em 1996, antes da "revolução" provocada pela internet.

CUNHA, D. A. C. Um olhar sobre vozes e poder no telejornal: o funcionamento do discurso 
Tudo o que se publica [na imprensa burguesa] é constantemente influenciado por uma ideia: servir à classe dominante, o que se traduz sem dúvida num fato: combater a classe trabalhadora. (...) E não falemos daqueles casos em que o jornal burguês ou cala, ou deturpa, ou falsifica para enganar, iludir e manter na ignorância o público trabalhador.

O campo da mídia (imprensa, rádio, televisão) funciona, portanto, para produzir ganhos e lucros aos seus proprietários. Segundo Bourdieu (1996), assim como o campo político e o campo econômico [...], o jornalístico depende do mercado, e está sujeito a sanções diretas da clientela e dos índices de audiência. Devido à concorrência, há uma uniformidade no caso da elaboração de notícias, pois não se pode não falar do que a concorrente cobre. Dessa forma, gera-se uma uniformidade dos produtos oferecidos, uma vez que a produção atua no sentido de “conservação dos valores estabelecidos” (BOURDIEU,1996, p. 108). Acrescentese que essa uniformidade é sobretudo ideológica, não só em razão dos donos das empresas pertencerem às elites financeiras, mas também porque os jornalistas que para elas trabalham têm os "mesmos" valores ou a "mesma" ideologia.

Os estudos sobre a mídia (BOURDIEU, 1996; SOUZA, 2016; RIEFFEL, 2014) apontam outras características relevantes, facilmente observáveis nos telejornais: a urgência que impede de fazer pensar; o nivelamento por baixo para atingir a maioria; o tratamento de temas com forte ressonância emocional no grande público; a responsabilidade de enunciar vereditos, intervindo nos debates por meio dos "intelectuais-jornalistas" convocados. As escolhas desses especialistas são para Bourdieu (1996, p. 85) "muito ameaçadoras", não só porque podem enganar os leigos, mas também porque alguns deles servem-se da sociologia para dar golpes no campo intelectual. Mais ainda: os intelectuais convocados "terão uma cota de televisão, um peso jornalístico sem comparação com seu peso em seu universo específico" (BOURDIEU, 1996, p. 86). Ele dá exemplos de intrusão de poderes da mídia, no campo científico, político e jurídico, colocando em questão os direitos de autonomia de cada campo. Nessa análise, Bourdieu (1996) postula que a influência do campo jornalístico sobre o campo político - um sujeito às pressões do mercado e outro do plebiscito - tende a enfraquecer a autonomia deste último. $\mathrm{O}$ mesmo ocorre com o campo jurídico na medida em que os que estão sempre disponíveis e dispostos a 
Linha D'Água (Online), São Paulo, v. 30, n. 1, p. 89-114, jun. 2017

participar e a fazer concessões para granjear notoriedade "na mídia" são escolhidos para formular pontos de vista em consonância com os daqueles que os convidam ${ }^{6}$.

No Brasil, a prática não é diferente, havendo especialistas em várias emissoras para fazer comentários, a exemplo dos professores Leandro Karnal (historiador) e Mário Sérgio Cortella (filósofo) sobre assuntos de diversos campos. Há telejornais, como por exemplo, o da TV Cultura, que têm seus "especialistas" para "analisar" cotidianamente os temas apresentados. No Jornal Nacional, as notícias sobre política são constituídas pela fala de um jornalista e de políticos cuidadosamente escolhidos. Dessa forma, a seleção dos políticos convocados é responsável pela construção social de eventos e pela capacidade de provocar efeitos de mobilização ou o contrário.

A televisão apesar da revolução que a internet provocou na área da cultura e do jornalismo, para ficar apenas nesses campos, é responsável pela bagagem informacional e política da maioria da população brasileira. De acordo com dados da "Pesquisa Brasileira de Mídia 2016 - Hábitos de Consumo de Mídia pela População Brasileira”, divulgada em janeiro, pela Secretaria de Comunicação Social do governo ${ }^{7}$, quase $90 \%$ dos brasileiros se informam pela televisão sobre o que acontece no país, dos quais $63 \%$ têm na TV o principal meio de informação. A internet ficou em segundo lugar, como meio preferido de $26 \%$ dos entrevistados e citada como uma das duas principais fontes de informação por $49 \%$. Ainda, conforme esse relatório, mais da metade dos entrevistados que assistem à televisão disseram que confiam sempre ou muitas vezes nas notícias veiculadas por esse meio, o que é um perigo para a democracia. A TV Globo continua sendo a mais vista pelo público, tendo sido mencionada por $73 \%$ dos entrevistados.

Esses dados sobre a audiência da informação televisiva bem como a construção composicional das notícias mostram a importância de análises das vozes no telejornal.

- Na França, a consagração pela mídia era levada em conta segundo o sociólogo francês até por comissões do Centre National de la Recherche Scientifique (CNRS). Segundo Bourdieu (1996, p. 90) os acadêmicos "mendigam convites, protestando pelo esquecimento a que são relegados", levando-o a fazer uma crítica ácida aos que colaboram com a mídia.

7 Disponível em: http://gl globo.com/economia/midia-e-marketing/noticia/tv-e-o-meio-preferido-por-63-dos-brasileiros-para-se-informar-e-internet-por-26-diz-pesquisa.ghtml. Acesso em: 11 fev. 2017

CUNHA, D. A. C. Um olhar sobre vozes e poder no telejornal: o funcionamento do discurso 
Linha D'Água (Online), São Paulo, v. 30, n. 1, p. 89-114, jun. 2017

\section{0 enquadramento teórico e interpretativo}

\section{1 Língua e linguagem}

É comum se opor linguagem ou discurso à língua, a primeira como objeto das análises do discurso e a segunda das abordagens da linguística descritiva ou funcional, segundo a qual ela é um objeto autônomo e homogêneo, cujas unidades são reiteráveis e submetidas a regras de combinação.

As análises do discurso consideram a linguagem como lugar do heterogêneo, em que o uso das unidades da língua vai significar de acordo com as situações, os contextos, os backgrounds e os modos de recepção dos sujeitos. A linguagem produz sentidos na relação com o não verbal, com outras semiologias e nos diversos modos de circulação e recepção, não havendo correspondência entre os sentidos das formas da língua e os sentidos do contexto. Daí a diversidade dos processos de interpretação e a possibilidade de conflito de interpretações. No mesmo contexto, um ato de fala pode ser interpretado como promessa, ameaça, brincadeira, tendo em vista que "o sentido é um acontecimento e não uma característica interna dos “enunciados-verdadeiros”. (FRANÇOIS, 1998: 29).

Um outro aspecto importante nessa visão de linguagem é que os signos são ao mesmo tempo força e capacidade de representação (FRANÇOIS, 2016). O dizer do outro age em cada sujeito com mais ou menos força, podendo afetar, colocar em movimento, entusiasmar, provocar indignação, culpa, vergonha etc. No entanto, o modo como cada um sente a força das palavras de si e dos outros difere bastante.

Além disso, a linguagem é carregada de afetos e valores. Embora exista uma tendência para se separar o afetivo do intelectual, considero, na perspectiva de Scheler (apud FRANÇOIS, 2014), que há reciprocidade entre afetos e valores que constituem o sujeito e a linguagem. Analisar a linguagem implica, portanto, lidar com a experiência própria de cada um, na produção e interpretação dos sentidos. Pode-se dizer de forma simplificada que uma das diferenças entre as abordagens - da linguagem e da língua - está no fato de que o estudo dos modos de funcionamento da linguagem considera os aspectos afetivos e axiológicos do verbal e do não-verbal, e não apenas as regularidades da língua. 
Linha D'Água (Online), São Paulo, v. 30, n. 1, p. 89-114, jun. 2017

\section{2 "Sujeito" e ponto de vista}

Essas duas noções estão associadas. A concepção bakhtiniana de homem singular, inacabado, heterogêneo que se constitui na relação com o outro na e pela linguagem é aqui adotada. Essa concepção articula a posição singular de cada ser ao espaço, ao tempo e ao ato carregado de tons emotivos-volitivos e de valores que chamo ponto de vista. Não temos exatamente a mesma percepção, os mesmos sentimentos, valores, pontos de vista, mas estamos sempre numa relação de comunidade (não de identidade) e diferenças. $\mathrm{O}$ sujeito que interpreta trabalha com características gerais de um dado discurso e seu modo de ser singular, bem como com a especificidade de seu modo de percebê-lo.

De forma bem sucinta, pode-se dizer que estamos sempre em face de pontos de vista, uma vez que estritamente falando não há fato puro e ou sentidos dissociados de vivências, afetos, que são portadores de valores. É do lugar único que o sujeito histórico ocupa que ele percebe e apreende alguns aspectos da "realidade" múltipla, especialmente os pertinentes para ele. "Ponto de vista" é assim definido como modo de perceber, de interpretar e tomar posição, de se relacionar com o mundo, com o outro e consigo mesmo "enquanto" (FRANÇOIS, 2015). Ele é dinâmico e contingente, comporta movimentos e modificações, pode ser objeto de reavaliações, reacentuações, mas pode ter uma constância e ser compatível com um outro.

Nessa perspectiva, não é possível não tomar uma posição, não ter um ponto de vista que pode ser mais ou menos explícito. Em suma, falar de ponto de vista significa que não lidamos com a noção de "verdade". Trata-se de compreender/interpretar sentidos e para isso há outras entradas para análise que o próprio texto pode apontar.

\subsection{Vozes, heterodiscurso, discurso reportado, discurso de outro}

As noções de vozes, de heterodiscurso, de discurso reportado, de discurso do outro estão ligadas a Bakhtin $(2015 ; 2003$; 1997) e a Volochinov (2010), pois os estudos desse fenômeno foram tratados, ao longo do tempo, pelas abordagens gramaticais e estilísticas como estilo direto, indireto e indireto livre. Os autores russos elaboraram uma das mais inovadoras abordagens do discurso do outro, partindo do 
Linha D'Água (Online), São Paulo, v. 30, n. 1, p. 89-114, jun. 2017

princípio dialógico e do enunciado como resposta. Nessa perspectiva, interessam não as formas de discurso reportado, mas o que o sujeito faz com o discurso do outro. Para isso, a análise passa a ser o diálogo, a interação entre as vozes, entre o discurso emoldurador e o enunciado citado, que revela a relação entre sujeitos. Retomo aqui a noção ampla de discurso reportado proposta em Cunha (1992), que inclui as formas marcadas e as não marcadas, que vão da citação à alusão, incluindo as formas de presença do outro interpretadas enquanto tais pelo destinatário.

A questão fundamental é que o enunciador tem sempre um interesse, um propósito quando retoma o discurso do outro: apreciar, julgar, reforçar seu ponto de vista, desenvolver o seu discurso, usar como argumento de autoridade, explicar, criticar, refutar etc. A posição em relação ao discurso do outro manifesta-se nas formas de enquadramento do dizeres do outro, nos comentários prévios ao discurso citado, nas reacentuações, na escolha das palavras, nas formulações etc. ${ }^{8}$

\section{4 $\mathrm{O}$ ato de nomear}

Uma vertente recente nos estudos dialógicos do discurso considera a nominação como um recurso dialógico. Já na década de 1920, Volochínov (2013), por exemplo, preconizava que todos os fenômenos são associados a valores, incluindo as palavras ${ }^{9}$, o material privilegiado para o estudo das ideologias. Assim, na perspectiva dialógica, são os julgamentos de valores que determinam o que falar, a entoação, a seleção das palavras e sua distribuição na organização do enunciado, bem como o que silenciar. Isso quer dizer que os nomes não dizem a essência das coisas nem colocam etiquetas nos objetos do mundo, nem refletem uma realidade comum, mas revelam a percepção e o ponto de vista do enunciador em relação ao objeto de discurso e aos que o nomeiam de forma diferente. Poderia ilustrar essa abordagem com o exemplo sobre o uso de presidente ou presidenta para nomear autoridades

8 Em trabalhos anteriores, o discurso do outro foi abordado em diversos gêneros, esferas, correlacionado com questões como pontos de vista, gênero, história, entre outras (CUNHA, 2002; 2008; 2009; 2011 ; 2013; VALOIS e CUNHA, 2012)

9 Em russo, slovo que, nos escritos de Volochínov e Bakhtin, pode significar também texto, discurso, linguagem, ou seja, toda produção oral ou escrita proferida por alguém no contexto espaço-temporal dado, podendo ser uma interjeição a um longo romance (SERIOT, 2008). 
Linha D'Água (Online), São Paulo, v. 30, n. 1, p. 89-114, jun. 2017

do sexo feminino. Em 2011, ao assumir a presidência da República, Dilma Roussef pediu para ser chamada de presidenta enquanto a ministra Cármen Lúcia, no dia da sua eleição para o cargo em 2016, disse que queria ser chamada de presidente do Supremo Tribunal Federal (STF), com o argumento de que é amante da língua portuguesa. Não é possível interpretar ou acreditar que se trata de uma questão puramente morfológica ou linguística. Não vou me deter na análise dessas escolhas em razão das diversas possibilidades de interpretações. Diria apenas que Dilma Roussef foi a primeira mulher eleita ao cargo num país governado majoritariamente por homens brancos o que foi um grande acontecimento histórico e político. Quanto à ministra Cármen Lúcia, pode-se ler que sua posição buscava marcar diferenças ou discordâncias ideológicas entre ambas.

Essa abordagem conhecida como dialogismo da nominação difere das abordagens lexicológicas que consideram o valor resultativo da denominação enquanto a primeira se interessa pelo valor processual, pelo ato valorativo, inseparável do ponto de vista ou do que comumente se chama ideologia. Nessa perspectiva, num mesmo ato, o enunciador em nomeia, categoriza e se revela, como quando se diz, por exemplo, que alguém fala de "preto de alma branca". Siblot (1998:29) considera que se pode mostrar por meio de um desvio da fórmula "diga com quem anda que eu direi quem você é", a relação dialética existente no processo de nominação: "diga-me como você nomeia, e eu direi quem você é" (aspas do autor).

Alguns trabalhos (SIBLOT, 2007, MOIRAND, 2006, VENIARD, 2013) destacam ainda a dimensão argumentativa do ato de nomear. Dessa forma, toda nomeação exprime uma visão da coisa nomeada, vista sob um certo ângulo, a partir do ponto de vista no qual se coloca o locutor.

\subsection{Uma nota sobre a noção de poder}

Partimos do ponto de vista de que as relações de poder são inerentes às relações humanas e não ocorrem apenas no âmbito do funcionamento dos aparelhos de Estado (FOUCAULT, 2003). São "relações de força, de pequenos enfrentamentos, micro lutas, de algum modo" (FOUCAULT, 2003, p. 231). Para o autor, "em toda parte, se está em luta - há, a cada instante, a revolta da criança, que põe seu dedo 
Linha D'Água (Online), São Paulo, v. 30, n. 1, p. 89-114, jun. 2017

no nariz à mesa, para aborrecer seus pais, o que é uma rebelião, se quiserem - e a cada instante se vai da rebelião à dominação, da dominação à rebelião" (FOUCAULT, 2003, p. 232). Essa noção em Foucault está ligada à questão da verdade que o autor prefere chamar de efeitos de verdade, uma vez que, para ele, a verdade "é um conjunto de procedimentos que permitem a cada instante e a cada um pronunciar enunciados que serão considerados verdadeiros, não havendo 'instâncias suprema”. Foucault considera duas regiões em que esses efeitos de verdade são codificados: nos domínios científicos e no sistema de informações.

\section{Questões metodológicas \\ 3.1 Situando o corpus}

O corpus desse estudo é uma notícia apresentada no Jornal Nacional, Conversa telefônica causa polêmica, no dia 17 de março de 2016 com duração de aproximadamente seis minutos (cinco minutos e quarenta e nove segundos para ser exata).

Para analisar um telejornal, é necessário considerar o lugar que a empresa de televisão ocupa do ponto de vista das relações econômica, ideológica e simbólica. Isso significa que é preciso saber "o poder específico que possui seu órgão de imprensa, que se mede por seu peso econômico e também por seu peso simbólico" (BOURDIEU, 1996, p. 58).

O Grupo Globo, como se sabe, é um império da comunicação, que atua em diversos segmentos (TV, rádio, jornais, revistas, filmes brasileiros, música etc.). $\mathrm{O}$ jornalista Roberto Marinho recebeu duas concessões: em 1957 para a Globo do Rio, e em 1962, para o canal da emissora em Brasília. ${ }^{10}$ Seus proprietários - João Irineu, João Roberto e José Roberto Marinho - são os homens mais ricos do Brasil, desde 1987, segundo levantamento publicado pela revista Forbes ${ }^{11}$.

10 Disponível em: http://memoriaglobo.globo.com/acusacoes-falsas/concessoes-de-canais. htm. Acesso em: 24 fev. 2017.

11 Disponível em: http://www.pragmatismopolitico.com.br/2016/03/os-10-homens-mais-ricos-do-brasil-e-do-mundo.html; http://economia.vol.com.br/noticias/redacao/2014/05/14/ marinho-e-a-familia-mais-rica-do-brasil-segundo-forbes-veja-lista.htm. Acesso em: 24 fev. 2017.

CUNHA, D. A. C. Um olhar sobre vozes e poder no telejornal: o funcionamento do discurso 
Linha D'Água (Online), São Paulo, v. 30, n. 1, p. 89-114, jun. 2017

O cientista político brasileiro, Wanderley Guilherme dos Santos, no artigo

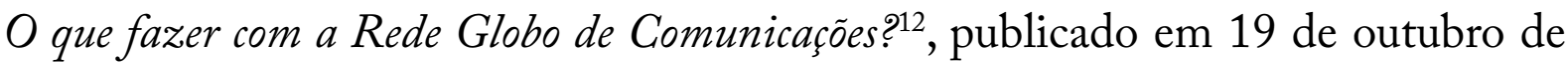
2016, escreve:

O Sistema Globo de Comunicações é modelo excepcionalmente bem-sucedido projeto de formação da opinião pública e de interpretação conjuntural dos valores cívicos da nacionalidade. É ele quem cria os amigos e os inimigos do País, mediante o controle, pelo medo, das instituições políticas e judiciárias.

A escolha do telejornal da Globo foi feita, em $1^{\circ}$ lugar, porque é a emissora de maior audiência no país, desde os anos 1970, mantendo liderança isolada no segmento de televisão aberta no Brasil. A TV Globo chega em todos os recantos do Brasil, nas comunidades longínquas da Amazônia ao Rio Grande do Sul, passando pelo Centro-oeste e Nordeste do país, nos lugares em que o único meio de informação é o Jornal Nacional..$^{13}$ É a mais vista do país justamente porque tem repetidoras em locais onde não chegam os sinais de outras emissoras. Tem ainda 30 canais pagos, entre eles a Globo Nerws descrito como "canal de notícias 24 horas no ar", que era o terceiro mais visto no Brasil em 2016 da TV por assinatura. ${ }^{14}$

O Jornal Nacional é atualmente apresentado pelo próprio editor, o jornalista William Bonner que seleciona os assuntos, cria a problemática, distribui e corta a palavra, ou seja, controla o tempo dedicado a cada assunto, inclusive da fala de cada entrevistado. Wiliam Bonner corresponde aliás à descrição que faz Bourdieu (1996, p. 64) dos apresentadores de telejornais franceses: "tornaram-se pequenos diretores de consciência que se fazem, sem ter que forçar muito, os porta-vozes de

12 Disponível em: http://insightnet.com.br/segundaopiniao/? $\mathrm{p}=430$ e http://segundaopiniao.jor.br/o-que-fazer-com-rede-globo-de-comunicacoes-por-wanderley-guilherme-dos-santos/. Acesso em: 24 out. 2016.

13 Ver a esse respeito a comunicação da jornalista Sue Branford, convidada a participar de um painel sobre Mídia, Percepção e a Consolidação da Democracia Brasileira, na Brazil Forum, em abril de 2016, para discutir temas ligados à crise que afastou a presidenta Dilma. Disponível em: https://www.youtube.com/watch?v=usPgv2M4ZIE Acesso em 04 fev. 2017.

14 Disponível em: https://tvefamosos.vol.com.br/noticias/ooops/2016/06/19/globonews -e-o-3-canal-pago-mais-visto-do-pais-veja-ranking-top-30.htm. Acesso em 04 fev. 2017.

CUNHA, D. A. C. Um ohar sobre vozes e poder no telejornal: o funcionamento do discurso 
Linha D'Água (Online), São Paulo, v. 30, n. 1, p. 89-114, jun. 2017

uma moral tipicamente pequeno-burguesa, que dizem 'o que se deve pensar' sobre o que chamam de 'os problemas de sociedade'."

\subsection{Contextualizando o evento estudado}

É necessário situar o contexto político do acontecimento, objeto da notícia sobre as reações à conversa telefônica entre Lula e Dilma. Em uma delas, o ex-presidente queixa-se da "República de Curitiba", uma referência ao juiz Moro, diz que o Supremo Tribunal Federal e o Superior Tribunal de Justiça estão “acovardados”, e o Congresso numa péssima situação com parlamentares ameaçados.

Contudo, para se compreender esse evento (e penso aqui na possibilidade de esse artigo ser lido não apenas em 2017), considero necessário trazer o contexto político mais amplo. Considero com Souza (2016) que os eventos políticos de 2016 estão numa linha de continuidade com as manifestações de junho de 2013, quando tem início uma série de manifestações, lideradas pelo Movimento Passe Livre (MPL) que lutava contra o aumento das passagens de ônibus em diversas capitais brasileiras, mais especialmente em São Paulo ${ }^{15}$. De acordo com Souza (2016, p. 90), essas manifestações foram inicialmente criticadas pela mídia conservadora, mas percebendo que tinha um potencial de crítica ao governo, os apresentadores do Jornal Nacional passaram a repetir "com rosto feliz e sorriso aberto" que tudo era "pacífico". Houve em seguida uma mudança nas bandeiras dos protestos: inflação e custo de vida substituíram a luta pela tarifa zero ao mesmo tempo em que o Jornal Nacional mostrava grande queda de popularidade da presidenta Dilma. Vale lembrar que o MPL se retirou do movimento porque o aumento das passagens foi revogado e que, no fim de junho de 2013, depois de numerosas manifestações gigantescas com o discurso contra a corrupção, o Jornal Nacional apresentou uma pesquisa de opinião cujos resultados apontavam que a popularidade da Presidenta caíra 27 pontos percentuais.

15 Grande parte dessa contextualização baseia-se em Souza (2016) que analisa as manifestações em São Paulo a partir do dia 12 de junho de 2013, com base nos conteúdos do Jornal Nacional, mas não só, para mostrar que a destituição da presidenta Dilma Roussef teve início com essas manifestações.

CUNHA, D. A. C. Um ohar sobre vozes e poder no telejornal: o funcionamento do discurso 
Linha D'Água (Online), São Paulo, v. 30, n. 1, p. 89-114, jun. 2017

Em 2014, houve a reeleição de Dilma Roussef com uma pequena diferença no número de votos para o seu adversário, Aécio Neves que exigiu a recontagem dos votos. A partir de novembro de 2014, começaram também prisões e "vazamentos seletivos" (SOUZA, 2016, p. 110) pela Operação Lava Jato ${ }^{16}$. Os telejornais publicaram seguidamente trechos de depoimentos que deveriam estar sob segredo de justiça. Entre março e agosto de 2015, houve numerosas manifestações em mais de duzentas cidades do país, com a grande exibição midiática, juntamente aos vazamentos seletivos. Em 4 de março de 2016, o ex-presidente Lula foi conduzido coercitivamente para depor em uma sala no Aeroporto de Congonhas. Nesse dia, um telefonema da presidenta Dilma Rousseff foi gravado com autorização do juiz federal Sérgio Moro. No dia 16 de março de 2016, a presidenta Dilma nomeia o ex-presidente para ser ministro da Casa Civil. Foi então que houve o vazamento ilegal de pelo menos duas conversas entre a presidenta e Lula. Uma delas foi feita logo após a condução coercitiva do ex-presidente, em 4 de março, e provocou as reações apresentadas na notícia analisada. $\mathrm{O}$ segundo áudio, feito dia 16 de março, contém um diálogo entre Dilma e Lula a respeito do "termo de posse", documento que confirma a nomeação para a Casa Civil. Tanto a condução coercitiva quanto os vazamentos foram considerados ilegais por vários juristas.

\section{Análise do vídeo}

A transcrição de uma notícia de telejornal tem grandes perdas, pois é impossível transcrever a entonação, os gestos, as expressões faciais, os movimentos dos corpos do apresentador, da repórter, dos sujeitos convocados, que têm um grande peso semântico: o modo de olhar para a câmara, as pausas, a entonação dada a palavras ou enunciados parecem estudados para produzir determinados efeitos de sentido. ${ }^{17}$

16 A Operação Lava Jato investiga crimes de corrupção, como doações de propinas pelos políticos para grandes empresas públicas como a Petrobras e privadas para fazer caixa 2 nas campanhas eleitorais entre outros crimes. Vale ressaltar que ela passa a dominar o espaço público a partir de 2014, com a acirrada disputa eleitoral para a presidência, "com a criminalização do PT [Partido dos Trabalhadores] e da base de apoio do Governo" (SOUZA, 2016, p. 107).

17 É por meio dessa linguagem não verbal que o telejornal explora o aspecto emocional, muito mais do que a reflexão. Esse aspecto, aliás, está na lista das dez estratégias de manipulação 
Linha D'Água (Online), São Paulo, v. 30, n. 1, p. 89-114, jun. 2017

Quanto ao verbal, os vídeos do Jornal Nacional sobre temas da política apresentam um certo padrão: os apresentadores William Bonner (editor-chefe) e Renata Vasconcellos leem o sumário das notícias. Em seguida, os apresentadores fazem a chamada de um repórter no local do evento. Ele introduz o discurso reportado seguido da fala em discurso direto de algum entrevistado. Esse esquema (fala do repórter seguida da introdução de outra voz) pode se repetir várias vezes. A notícia pode ser encerrada pela voz convocada pelo apresentador ou pelo repórter. A notícia Conversa telefônica causa polêmica é constituída por um enunciado do editor e apresentador, William Bonner, de oito enunciados da jornalista Mariana Bonfim, que reporta cinco falas em discurso direto e uma em discurso indireto dos sujeitos mencionados na fala dela.

Um aspecto fundamental no telejornal é, portanto, a seleção dos discursos convocados para compor a notícia. No caso do vídeo a seguir, o apresentador escothe algumas "autoridades da República" que criticam o ex-presidente Lula:

William Bonner: o conteúdo (tom enfático) das conversas do ex-presidente provocou reações indignadas de autoridades da República.

$\mathrm{Na}$ fala do editor, chamam atenção a ênfase dada por meio da entonação à palavra "conteúdo"; a escolha da qualificação das reações - "indignadas"; e a forma de nomear os agentes das reações - "autoridades da República". Essas escolhas são feitas para produzir determinados efeitos, como por exemplo, impressionar e atribuir respeito a esses agentes e levar o público a ter o mesmo tipo de reação (de indignação). Esse contexto emoldurador introduz a voz off da jornalista da emissora, que por sua vez avalia e introduz as falas das "autoridades da república":

No Supremo Tribunal Federal ${ }^{18}$, reações em discursos firmes ${ }^{19}$. O decano, ministro mais antigo do tribunal, Celso de Melo (imagem do ministro discursando

da mídia apontadas por Chomsky (2010).

18 Voz off da jornalista, imagem de Celso de Mello no primeiro plano, seguida de um plano geral da sessão do plenário do Supremo Tribunal Federal, e novamente imagem do Ministro em primeiro plano. A classificação dos planos foi feita com base no site: http://cameracotidiana. com.br/saladeaula/tema/plano/

19 Doravante, STF no artigo, exceto na transcrição das falas do telejornal.

CUNHA, D. A. C. Um ohar sobre vozes e poder no telejornal: o funcionamento do discurso 
Linha D'Água (Online), São Paulo, v. 30, n. 1, p. 89-114, jun. 2017

\begin{abstract}
com áudio) foi taxativo no plenário e respondeu assim à afirmação do ex-presidente Lula em conversas gravadas de que o Supremo está acovardado: "Os meios de comunicação revelaram ontem que conhecida figura política de nosso país em conversa telefônica com uma terceira pessoa ofendeu gravemente a dignidade institucional do poder judiciário, imputando a este tribunal a grosseira e injusta qualificação de ser, abro aspas, uma suprema corte totalmente acovardada, fecho aspas. Esse insulto ao poder judiciário, além de absolutamente inaceitável e passível da mais veemente repulsa por parte dessa corte suprema, traduz no presente contexto da profunda crise moral que envolve os altos escalões da República uma reação torpe e indigna típica de mentes autocráticas e arrogantes que não conseguem esconder até mesmo em razão do primarismo do seu gesto leviano e irresponsável o temor pela prevalência do império da lei e o receio pela atuação firme, justa impessoal e isenta de juízes livres e independentes.”
\end{abstract}

A repórter constrói a notícia, usando a localização dos falantes, categorizando e qualificando as falas - "reações em discursos firmes" - e o ministro - "taxativo"-, reiterando o ponto de vista do editor. $\mathrm{Na}$ realidade, essas escolhas podem ser consideradas eufemismos, quando se lê a fala do ministro. Da mesma forma que o editor, a jornalista, ao qualificar o ministro de "decano", revela o respeito por ele e o valor da fala do juiz mais antigo, mais experiente e consequentemente com mais conhecimento acumulado.

Embora o foco seja o discurso citante, aponto muito brevemente a escolha das palavras, epítetos e argumentos da fala citada do juiz, em terceira pessoa, o que produz o efeito de verdade e impessoalidade. $\mathrm{O}$ juiz categoriza como "grosseira e injusta a qualificação" ao STF feitas por Lula; "reação torpe e indigna"; "gesto leviano e irresponsável". Além disso, o conteúdo da gravação é "absolutamente inaceitável e passível da mais veemente repulsa"; decorrente de "profunda crise moral" por que passam "os altos escalões da República”. O presidente tem uma mente primária, autocrática e arrogante. Por outro lado, a categoria dos juízes tem "atuação firme, justa impessoal e isenta"; e os juízes são "livres e independentes."

Observe-se que o ato de nomear desqualifica não só o discurso, mas o autor do discurso, o que tem consequências, sobretudo em razão do lugar ocupado pelo ministro do STF, e levanta, como propõe Moirand (2016), a questão da dimensão 
Linha D'Água (Online), São Paulo, v. 30, n. 1, p. 89-114, jun. 2017

moral da responsabilidade enunciativa e da ética. A violência verbal não é um ato aceitável do ponto de vista ético.

Em seguida, a repórter introduz apenas com o verbo falar o discurso direto do presidente do STF:

O presidente do $\mathrm{STF}^{20}$, Ricardo Levandowski falou logo depois: "Eu queria dizer que os constituintes de 1988 atribuíram a esta suprema corte a elevada missão de manter a supremacia da constituição federal e a manutenção do estado democrático de direito, e eu tenho certeza de que os juízes dessa casa não faltarão aos cidadãos brasileiros no cumprimento deste elevado monte."

As falas parecem ter sido escolhidas para alternar o tom emotivo-volitivo e o peso axiológico delas. A fala do presidente do STF apresenta uma nota num tom ponderado, sem acusações ou alusões ao ex-presidente, reiterando o papel institucional do STF e a responsabilidade dos juízes.

No enunciado seguinte, a jornalista situa o local da gravação, repete a acusação do ex-presidente Lula, escolhe o verbo reagir, que não tem um valor negativo nesse contexto, e diz que a acusação também foi dirigida ao Supremo Tribunal de Justiça (STJ):

No Supremo Tribunal de Justiça, ${ }^{21}$ que Lula também acusa de estar acovardado, o ministro João Otávio de Noronha reagiu: "Esta casa não é uma casa de covardes, essa casa é uma casa de juízes, juízes íntegros, que não recebem doações de empreiteiras. É estarrecedor (sic)a ironia, o cinismo daqueles que cometem o delito e querem se esconder atrás de uma falsa alegada violação de direito. Diz que se revelou o que não poderia revelar, mas não se nega (sic) os fatos e porque não tem como negar aquilo que tá gravado. A atitude do juiz Moro goste ou não certa ou errada

20 Voz off da jornalista, imagem de Ricardo Lewandowski no primeiro plano, seguida de um plano geral da sessão do plenário do Supremo Tribunal Federal, e novamente imagem do Ministro em primeiro plano.

${ }^{21}$ Voz off da jornalista, imagem da sessão do plenário do Supremo Tribunal de Justiça em plano geral, com inserção de enquadramento do juiz no centro da tela numa espécie de plano de detalhe (anexol). É importante destacar a montagem aqui, que é diferente das anteriores, certamente por questões técnicas. A notícia começa com um plano geral do Plenário do TSJ mostrando o conjunto dos juízes em audiência e, no enquadramento menor no centro da tela, o juiz Noronha extremamente exaltado.

CUNHA, D. A. C. Um ohar sobre vozes e poder no telejornal: o funcionamento do discurso 
Linha D'Água (Online), São Paulo, v. 30, n. 1, p. 89-114, jun. 2017

revelou a podridão que se esconde atrás do poder. Se alguns caciques do judiciário se incomodam ou se o invejam do prestígio (sic) que ele adquiriu, lamento."

Chama atenção a forma de introdução da fala pela jornalista: por um lado ela repete a acusação de Lula que gerou reações, algumas violentas, de juízes, de procuradores, do presidente do Senado etc. Por outro, ela parece neutra porque não qualifica a violenta reação do juiz Noronha, que faz o discurso mais agressivo, por meio de palavras, de entonação, de expressão facial, de gestos, aparentando um ódio exacerbado ao ex-presidente. Não só ele usa o dedo em riste, mas também faz movimentos levantando os dois braços ao mesmo tempo durante a sua fala. No seu discurso também na terceira pessoa, ele qualifica os juízes - "íntegros, que não recebem doações de empreiteiras" -, numa alusão às acusações feitas ao ex-presidente pelo juiz Sérgio Moro. João Otávio Noronha defende de forma velada este último ao lamentar a atitude de "caciques do judiciário" que se incomodam ou invejam o prestígio do colega. Faz alusão à ilegalidade das gravações da fala do ex-presidente, acusando-o de "cinismo estarrecedor" e de cometer delito. No final do trecho citado, aparece a primeira pessoa ("lamento"), o que torna evidente que se trata de opinião pessoal.

A notícia continua com o acréscimo de outras reações relatadas pela jornalista:

Os investigadores da Lava Jato ${ }^{22}$ também falaram. Em Curitiba, ${ }^{23}$ o procurador Deltan Dallagnol reforçou que as investigações contra Lula foram pedidas pelo Ministério Público: "Os atentados à investigação revelam a extensão do abuso do poder e do descaso com o Estado Democrático de Direito na República. As conversas telefônicas constituem evidências de obstrução às investigações em uma guerra desleal e subterrânea travada nas sombras longe dos tribunais. $\mathrm{O}$ estado democrático não existe sem o direito, não há direito sem poder judiciário independente. Não há independência do poder judiciário sem que sejam respeitadas

22 Voz off da jornalista, imagem rápida (3 segundos) em plano médio de um homem de paletó e gravatá, possivelmente investigador rodeado de pessoas com bandeiras do Brasil.

23 Voz off da jornalista, imagem em plano médio do procurador Dallagnol cercado por outros procuradores que lê um texto para muitos jornalistas. Aparecem vários microfones e celulares gravando o seu depoimento e parte da bandeira do Brasil segurada por alguém que está fora do enquadramento da câmera.

CUNHA, D. A. C. Um ohar sobre vozes e poder no telejornal: o funcionamento do discurso 
Linha D'Água (Online), São Paulo, v. 30, n. 1, p. 89-114, jun. 2017

as suas decisões. A força das investigações da Lava Jato deriva da busca da verdade e da justiça com base em princípios e regras, comungados, compartilhados com a sociedade e estabelecidos na Constituição."

A fala da jornalista inicia-se com um discurso indireto, seguido da localização e da indicação de quem fala bem como do ato de fala relatado. Em seguida, ela dá voz a Delton Dallagnol.

A fala do procurador é carregada de acusações ao ex-presidente: cometer "atentados à investigação", "abuso do poder e descaso com o estado democrático de direito na República"; obstrução às investigações; travar "uma guerra desleal e subterrânea travada nas sombras longe dos tribunais". Por outro lado, ele defende as investigações da Lava Jato e o poder judiciário.

A declaração do procurador é cortada e entra a primeira imagem em plano médio da jornalista com sua identificação: Camila Bonfim.

Aqui em Brasília, mais um ato (ela aponta para a imagem de manifestação dos juízes atrás dela) em defesa das investigações e do juiz Sérgio Moro. Os juízes pediram uma justiça independente e sem intimidações.

Vê-se mais uma vez o formato recorrente da notícia: localização do evento (aqui em Brasília) e introdução do discurso reportado. Mas aparece a imagem da jornalista na frente de um evento em que um juiz lê um documento, cercado por vários outros, todos de toga, segurando uma faixa verde e amarela que vai da altura do ombro até os pés e uma bandeira do Brasil, emblema das classes conservadoras nas manifestações, a partir de junho de 2013, contra a corrupção, contra o governo Dilma e o Partido dos Trabalhadores. Mas a repórter não dá voz a esses últimos, ela mesmo reportando num discurso indireto os dois atos de fala - (juízes) fizeram ato em defesa das investigações e do juiz Sérgio Moro e pediram uma justiça independente e sem intimidações.

A jornalista Mariana Bonfim dá um destaque maior às declarações do procurador geral da República que se encontrava na Suíça: 
Da Suíça ${ }^{24}$, o procurador Rodrigo Janot também rebateu Lula. Disse que o Ministério Público não tem medo: “O Ministério Público tem que ter couro grosso, o Ministério Público mexe com a liberdade das pessoas, com o patrimônio das pessoas e é normal que as pessoas reajam. O Ministério Público tem que agir com tranquilidade, tecnicamente, mas destemidamente. Ministério Público não tem medo de nada". Lula (imagem do ex-presidente) se referindo a Janot na gravação falou em falta de gratidão (imagem de Janot falando): "Não sei que ingratidão, gratidão é essa, o que posso dizer é que entrei no meu cargo por concurso público, tenho trinta e dois anos de carreira, percorri toda a minha carreira, tô sou (sic) em final de carreira e se eu devo a alguém esse meu cargo é a minha família.”

Mais uma vez, ela situa o local do entrevistado (da Suíça), categoriza o ato de fala de Janot - "rebateu" Lula -, e, antes de inserir essa voz dele, faz uma paráfrase em discurso indireto de parte da fala dele. $\mathrm{Na}$ montagem da notícia, a fala do procurador é cortada para que a jornalista dê uma explicação da sequência final - "Lula se referindo a Janot na gravação falou em falta de gratidão". Na declaração, embora a jornalista o incite a responder à fala do ex-presidente, o procurador Rodrigo Janot, assim como o ministro Lewandowski fez em relação ao STF, fala do papel institucional do Ministério Público. Embora o enunciado "o Ministério Público mexe com a liberdade das pessoas, com o patrimônio das pessoas e é normal que as pessoas reajam”seja genérico, pode-se interpretá-lo como como uma “ alfinetada" em Lula, pela crítica à ingratidão. ${ }^{25}$

$\mathrm{Na}$ sequência final, Mariana Bonfim relata a fala do presidente do Senado ${ }^{26}$ :

O presidente do senado Renan Calheiros falou do tom pejorativo com que foi tratado na gravação com Lula. Disse que comentários ofensivos não fazem bem à democracia: "Eu acho que qualquer comentário e talvez o grampo atenda nesse

24 Entra a imagem do procurador geral da República, Rodrigo Janot, na Suíça, caminhando, cercado por jornalistas. Enquanto a jornalista fala, ele para e dá uma entrevista transmitida nessa notícia.

25 Rodrigo Janot foi nomeado procurador geral da República em 2013 pela presidenta Dilma Roussef.

26 Imagem de Renan Calheiros saindo de um corredor largo, acompanhado por agentes de segurança e repórter.

CUNHA, D. A. C. Um olhar sobre vozes e poder no telejornal: o funcionamento do discurso 
Linha D'Água (Online), São Paulo, v. 30, n. 1, p. 89-114, jun. 2017

sentido que desmereça as instituições ou colabore com o enfraquecimento das instituições não é bom para a democracia.” (sic)

O discurso direto de Renan Calheiros não contém o conteúdo que é relatado pela jornalista em discurso indireto - "O presidente do senado Renan Calheiros falou do tom pejorativo com que foi tratado na gravação com Lula”. Certamente por questões de edição e de tempo, a parte da declaração do senador que menciona o tom pejorativo não aparece na notícia.

\section{Considerações finais}

A característica mais visível do telejornal da Rede Globo do ponto de vista composicional é a presença da jornalista fora do estúdio, algumas vezes no local do evento, que introduz discursos reportados, a maior parte em discurso direto, onde se mostram e se escutam "autoridades" políticas ou no assunto. $\mathrm{O}$ discurso introdutor e, às vezes, indireto é a base do discurso da jornalista, mediadora das falas entre os mundos dos discursos e o telespectador. Ela interpreta e categoriza o ato de fala do outro, a maior parte das vezes para mostrá-lo. Essa construção composicional é semelhante a de telejornais franceses (VON MÜNCHOW, 2004): lá, os jornalistas que reportam os discursos diretos assumem o papel de expositores de discursos, um lugar de passagem mais do que de transmissão de conhecimentos, ainda segundo a pesquisadora. A autora cita Charaudeau (1997, apud VON MÜNCHOW, 2004), para quem dar a fala a notáveis pode significar seriedade e, ao mesmo tempo, dar margem a suspeição. Na paisagem televisual francesa por ela analisada, mesmo seguindo esse formato, alguns telejornais são mais argumentativos, com mais apreciações do ato de enunciação relatado.

$\mathrm{Na}$ notícia analisada, destaca-se, em primeiro lugar, a escolha da "pauta", das vozes de "notáveis" para responder ao país, de forma violenta, ao conteúdo dos grampos do ex-presidente Lula em conversa com a presidenta Dilma Roussef. Em segundo lugar, o discurso emoldurador da jornalista, curto e aparentemente neutro. No entanto, ela não só categoriza, mas também repete trechos da fala do ex-presidente, desempenhando, como em notícias policiais, o papel de bombeiro incendiário, que "põe lenha na fogueira" para explorar a emoção despertada pelo 
Linha D'Água (Online), São Paulo, v. 30, n. 1, p. 89-114, jun. 2017

acontecimento e provocar reações da população contra o ex-presidente. Destacase igualmente o tempo das falas mais longas são dos juízes Celso de Mello e José Nogueira, e do procurador Dalton Dalagnol que proferiram os discursos mais agressivos, com poder de destruir reputação. A "longa” duração das falas funciona como argumento de autoridade para ilustrar e acentuar os pontos de vista velados da empresa, do editor, dos apresentadores e da jornalista.

Finalmente, sobressai-se a inexistência de pluralidade de opinião face ao evento, produzindo uma homogeneidade de pensamento, que vai de encontro às regras do jornalismo que é de se ouvir no mínimo "os dois lados", a favor e contra e ao que está escrito na página do Grupo Globo como definição do jornalismo: "Pratica jornalismo todo veículo cujo propósito central seja conhecer, produzir conhecimento, informar. O veículo cujo objetivo central seja convencer, atrair adeptos, defender uma causa, faz propaganda." ${ }^{27}$

Essa leitura não teve a pretensão de apresentar resultados sobre "o poder da mídia”, como fazem as abordagens globais de outros campos, mas mostra que uma análise do discurso pode revelar traços do gênero telejornal, do ponto de vista composicional, semântico e ideológico bem como o poder dos jornalistas que se inscreve no nível enunciativo.

\section{Referências}

BAKHTIN, Mikhail. Teoria do romance I. A estilística. Tradução por Paulo Bezerra. São Paulo: Editora 34, 2015.

. Estética da criação verbal. Tradução por Paulo Bezerra. 4.ed. São Paulo: Martins Fontes, 2003.

. Problemas da poética de Dostoieruski. Tradução Paulo Bezerra. 2.ed. Rio de Janeiro: Forense-Universitária, 1997.

27 Disponível em: http://grupoglobo.globo.com/breve_definicao_jornalismo.php. Acesso em: 10 mar. 2017.

CUNHA, D. A. C. Um olhar sobre vozes e poder no telejornal: o funcionamento do discurso 
Linha D'Água (Online), São Paulo, v. 30, n. 1, p. 89-114, jun. 2017

BOURDIEU, Pierre. Sobre a televisão, seguido de A influência do jornalismo e Os jogos olímpicos. Tradução por Maria Lúcia Machado. Rio de Janeiro: Jorge Zahar Ed., 1997.

CHOMSKY, Noam. Chomsky e as 10 Estratégias de Manipulação Midiática, 2010. Disponível em: http://www.institutojoaogoulart.org.br/noticia.php?id=1861. Acesso em 03 mar. 2017.

Controle da mídia: os espetaculares feitos da propaganda. Rio de Janeiro: Graphia, 2003.

CISLARU, Georgeta. et al. L'acte de nommer. Une dynamique entre langue et discours. Paris: Presse Sorbonne Nouvelle, 2007, 237p.

CORDEIRO, Rafaela Queiroz Ferreira. Nominações, vozes e pontos de vista sobre a loucura na e pela mídia: da reforma psiquiátrica ao boom das doenças mentais. Tese de doutorado, Universidade Federal de Pernambuco, 2017, 474p.

CORDEIRO, Rafaela Queiroz Ferreira. A construção discursiva dos eventos pela mídia: o processo de nominação e a representação do discurso outro. Dissertação de mestrado. Recife: PgLetras/ UFPE, 2011. Disponível em: <http://www.pgletras.com.br/autores/diss2011-Rafaela-QueirozCordeiro.html>. Acesso em: 03 mar. 2017.

CUNHA, Dóris de Arruda Carneiro da. O outro no discurso - representação e circulação. Revista do GELNE. v.1/2, p. 371-397, 2013.

Formes et degrés d'orientation dialogique, genre et point de vue In: L'Hétérogène à l'oeuvre dans la langue et les discours, Hommage à Jacqueline Authier-Revuz. Limoges: Lambert-Lucas, 2012, v.1, p. 289-302.

Formas de presença do outro na circulação dos discursos. Bakbtiniana, Revista de estudos do discurso. São Paulo, v. 1, n.5, 2011, p. 116-132.

Circulação, reacentuação e memória na imprensa. BAKHTINLANA, Revista de estudo do discurso. São Paulo, Número 2, 2009, p. 23-39.

Do discurso citado à circulação dos discursos: a reformulação bakhtiniana de uma noção gramatical. Matraga, n. 22, p. 129-144, 2008.

CUNHA, D. A. C. Um ohar sobre vozes e poder no telejornal: o funcionamento do discurso 
Linha D'Água (Online), São Paulo, v. 30, n. 1, p. 89-114, jun. 2017

. O funcionamento dialógico em notícias e artigos de opinião. In: BEZERRA, Maria Auxiliadora.; DIONÍSIO, Ângela Paiva.; MACHADO, Anna Rachel. (org.). Gêneros textuais e ensino. Rio de Janeiro: Lucerna, 2002. p. 166-179.

Discours rapporté et circulation de la parole. Leuven/Louvain-la-Neuve: Peeters/Louvain-la-Neuve, $1992.231 \mathrm{p}$.

DINES, Alberto; VOGT, Carlos. MELO, José Marques de. (orgs) A imprensa em questão. Campinas, SP: Editora da Unicamp, 1997, $181 \mathrm{p}$.

FOUCAULT, Michel. Estratégia, poder-saber. Rio de Janeiro: Forense Universitária, 2003.

FRANÇOIS, Frédéric. Dialogismo das "vozes" e heterogeneidade constitutiva do sentido. O "literário": semelhanças e diferenças de acentuação em Volochinov, Bakhtin e Vigotski. Tradução de Dóris de Arruda Carneiro da Cunha. Fórum Linguístico, Florianópolis, v. 13, n. 2, p. 1260-1294, jul. 2016. Disponível em: <https://periodicos.ufsc.br/index.php/forum/article/ view/1984-8412.2016v13n2p1260/32096>.

.Introduction. Quelques points de vue sur point de vue. CARCASSONNE, Marie, CUNHA, Dóris de Arruda Carneiro da., DONAHUE, Christiane., FRANÇOIS, Frédéric. In: Points de vue sur point de vue. Un essai de réflexion collective. Limoges: Lambert-Lucas, 2015a, p. 7-75.

. Le discours et ses entours. Essai sur l'interprétation. Paris: L'Harmattan, 1998.

GRAMSCI, Antonio. Os Jornais e os Operários. Texto de 1916. Transcrição de Alexandre Linares para o Marxists Internet Archive. HTML de Fernando A. S. Araújo para o Marxists Internet Archive, Jun. 2005. Disponível em: https:/www.marxists.org/portugues/gramsci/1916/mes/ jornais.htm\#topp. Acesso em: 3 fev. 2016.

MCCOMBS, Maxwell.; SHAW, Donald. The Agenda-Setting Function of Mass Media. In: The Public Opinion Quaterly, v. 36, n. 2. (Summer, 1972). Published by Oxford University Press, p. 176-187. Disponível em: http://www.unc.edu/ fbaum/teaching/PLSC541_Fall06/McCombs\%20and\%20Shaw\%20POQ\%201972.pdf. Acesso em: 3 fev. 2016.

MOIRAND, Sophie, La construction de lévénement dans la presse entre sémantique discursive, hétérogénéités énonciatives et inscription de l'émotion, postface et bibliographie 2016. In

CUNHA, D. A. C. Um olhar sobre vozes e poder no telejornal: o funcionamento do discurso reportado no Jornal Nacional da Rede Globo 
Linha D'Água (Online), São Paulo, v. 30, n. 1, p. 89-114, jun. 2017

Postface à la traduction en espagnol des Discours de la presse quotidienne, Paris: PUF, 2007. Buenos Aires, à paraître.

L'événement saisi par la langue et la communication. In: Cabiers de praxématique, Université de Montpellier, n. 63, 2014, p. 1-25.

Des façons de nommer 'les jeunes' dans la presse quotidienne nationale », dans la revue Adolescence, Revue trimestrielle de psychanalyse, psychopathologie et sciences humaines, tome 27, n. 70, « Langages », 2009, p. 907-919.

Les discours de la presse quotidienne. Observer, analyser, comprendre. Paris: PUF, février 2007.

De la nomination au dialogisme: quelques questionements autour de l'objet de discours e de la mémoire des mots. In: CASSANAS, Armelle; DEMANGE, Aude; LAURENT, Bénédicte; LECLERC, Aude. Dialogisme et nomination. Montpellier, Publications de l'Université de Montpellier 3, 2004, p. 27-61.

RAMONET, Ignacio. Le cinquième pouvoir. Le monde diplomatique, octobre 2003, p. 1-26. Disponível em: https://www.monde-diplomatique.fr/2003/10/RAMONET/10395. Acesso em: 12 mai. 2016.

RIEFFEL, Rémy. Révolution numérique, révolution culturelle? Paris: Gallimard, 2014.

SERIOT, Patrick. Traduire la langue ou traduire le discours : à propos de Marxisme et philosophie du langage de Volochinov. In: Actes du colloque Traductions scientifiques E' transferts culturels 1, Université de Lausanne, 2008, 5-15.

SIBLOT, Paul. De l'un à l'autre. Dialectique et dialogisme de la nomination identitaire. In: BRÈS, Jacques; DELAMOTTE-LEGRAND, Régine; MADRAY-LESIGNE Françoise; SIBLOT, Paul. (Éds). L'Autre en discours, Montpellier: Publications de l'Université Paul Valéry - Montpellier 3, 1998, p. 27-43.

. Nomination et point de vue: La composante déictique des catégorisations lexicales. In: L'acte de nomme: Une dynamique entre langue et discours. Paris: Presses Sorbonne Nouvelle, 2007, p. 25-38.

CUNHA, D. A. C. Um olhar sobre vozes e poder no telejornal: o funcionamento do discurso 
Linha D'Água (Online), São Paulo, v. 30, n. 1, p. 89-114, jun. 2017

SOUZA, Jessé de. A radiografia do golpe: entenda como e por que você foi enganado. Rio de Janeiro: LeYa, 2016.

A tolice da inteligência brasileira. Ou como o país se deixa manipular pela elite. Rio de Janeiro: LeYa, 2016.

TOBACK, Els.; JACOBS, Geert. (2013), Un regard ethnographique sur la production du journal télévisé. Le traitement des sonores en langue étrangère à la RTBF. In: LONDEI, Danielle. et al. (éds) Dire l'événement. Langage, mémoire, société. Paris, Presses Sorbonne Nouvelle, 2013, p. 99-111.

VON MÜNCHOW, Patricia. Les journaux télévisés en France et en Allemagne - Plaisir de voir ou devoir de s'informer. Paris: PUF, 2004.

VALOIS, Michelle; CUNHA, Dóris de Arruda Carneiro da. La bivocalité dans un récit autobiographique. Le discours et la langue. Vol. 2, 2012, p. 37-48.

VENIARD, Marie. La nomination des événements dans la presse. Essai de sémantique discursive. Besançon: Presses universitaires de Franche-Comté, 2013.

VOLOCHÍNOV, Valentin Nikolaïevitch. A construção da enunciação e outros ensaios. São Carlos: Pedro e João Editores, 2013.

. Marxisme et philosophie du langage. Les problèmes fondamentaux de la méthode sociologique dans la science du langage, Traduit par Patrick Sériot et Inna Tylkowski-Ageeva, Limoges, Lambert-Lucas, 2010, $1^{\text {ère }}$ édition : Leningrad, 1929.

Recebido em 12/03/2017.

Aprovado em 25/07/2017.

CUNHA, D. A. C. Um olhar sobre vozes e poder no telejornal: o funcionamento do discurso 